\title{
The Effect of Nano Fertilizer on Teff Yield and Yield Components in Ethiopia
}

\author{
Mersha Tezera \\ Esmeralda Farms, Bahir Dar, Ethiopia \\ Email address: \\ mertez19@yahoo.com \\ To cite this article: \\ Mersha Tezera. The Effect of Nano Fertilizer on Teff Yield and Yield Components in Ethiopia. International Journal of Applied Agricultural \\ Sciences. Vol. 7, No. 5, 2021, pp. 237-241. doi: 10.11648/j.ijaas.20210705.14
}

Received: September 7, 2021; Accepted: October 5, 2021; Published: October 30, 2021

\begin{abstract}
Nano technology increases the nutrient use efficiency. The experiment to test nano fertilizers on tef was conducted at the teff crop producing areas of Adet, Meray, and Meshenti areas. A total of sixteen fertilizer combinations of urea, DAP (Di Amonium phosphate) and Nano fertilizers including without fertilizer and without nano checks were tested on $2 \mathrm{~m} X 1.5 \mathrm{~m}$ plot size. The materials were planted in RCBD (Randomized Complete Block Design) with three replications. Spacing between replications and plots were 1 meter and 0.5 meter respectively. The seed and fertilizer rates were used as per recommendation rate per hectare bases. The nano fertilizer was tested as early as seed dressing and field spray during tillering stage. The performances of nano fertilizer over all locations have shown consistence results at all locations. Analysis of variance showed that there is a significant difference between the treatments for all parameters including grain yield. The highest grain yield (38 $\mathrm{Q} /$ ha) was recorded at the treatment combination of $2 \mathrm{gm} / \mathrm{ha}$ nano seed dressing, $39 \mathrm{~g}$ DAP and $10.8 \mathrm{~g}$ urea. And the least grain yield $(2.5 \mathrm{Q} / \mathrm{ha})$ was recorded at treatment combination of no nano and no fertilizer treatments. Here all nano treatment combinations without DAP and urea fertilizers gave grain yield less than $7 \mathrm{Q} /$ ha. Which implies that Nano fertilizers cannot act solely without DAP and Urea. The least maturity date (119 dates) and the highest plant height $(132.4 \mathrm{~cm})$ was also recorded at a treatment combination of $2 \mathrm{gm} / \mathrm{ha}$ nano seed dressing, $39 \mathrm{~g}$ DAP and $10.8 \mathrm{~g}$ urea. This implies that the crop at these treatments was vigor and was able to mature early.
\end{abstract}

Keywords: Nano, Tef Seed Dressing, Spray, Tillering, Days to Maturity, Grain Yield

\section{Introduction}

Agriculture is always the backbone of many developing countries. It does not only fill the people abdomen but also it is the part of economy. In concern of providing food to continuously growing population there has to be a new technology giving more yields in short period. In agriculture the main reason to use fertilizer is to give full-fledged macro and micro nutrients which usually soil lacks. To overcome all these drawbacks a smarter way i.e., nanotechnology can be one of the source. Since fertilizers are the main concern, developing nano based fertilizer would be a new technology in this field. The inorganic fertilizers are supplied in order to provide three main components namely nitrogen, phosphorous and potassium [4]. Nanotechnology increases the Nutrient use efficiency (NUE) and it also provides stress tolerating ability. Irrespective of the type of crop it can be used, it will be the complete bio source increasing the eco friendly nature builds carbon uptake, improves soil aggregation. Nanotechnology is gathering information of atom in nano scale range, with considering the physical, catalytic, magnetic, optical properties [11]. However, the technology chronically exposes soil microbes and micro fauna, as well as the plants themselves, to level of chemical reactivity that may be toxic [15]. Nano fertilizer is used to improve soil fertility, plant productivity and quality of agricultural products [6]. Nano-fertilizers may be absorbed by plants rapidly and completely [10]. Nano fertilizer is the most important field of agriculture and has more attention due to its capability to increase yield, improve soil fertility, reduce pollution and make a favorable environment for microorganisms [7]. The Nano fertilizers provide more surface area for different metabolic reactions in the plant which increases the rate of photosynthesis and produce more dry matters and yield of the crops, it has a slower release with uniform quantities compared to the conventional 
fertilizer application [13]. Nowadays farmers are striving to overcome nutrient deficiency by using more amounts of synthetic inorganic fertilizers [14]. There is more attention for nanotechnology in the agricultural sector and great potentials for it is higher reactivity, enhanced bioavailability and bioactivity, adherence effects and surface effects of nanoparticles [9]. Nanotechnology as a novel science has a good scenario for achieving sustainable agriculture, particularly in developing countries [2]. Nano-fertilizers are necessary to increase plant growth and crop productivity, and implement fruit quality through improvement nutrients efficiency and providing optimum usage of nutrients [1]. Heavy use of nitrogen $(\mathrm{N})$ and phosphorus (P) fertilizers causes eutrophication problems in freshwater bodies and coastal ecosystems world-wide [3] and [5]. Heavy use of nitrogen $(\mathrm{N})$ and phosphorus $(\mathrm{P})$ fertilizers is responsible for serious environmental pollution [8]. Production of nanofertilizers can be increased the value chain of the entire agriculture production system [12].

Objective

To test and recommend Nano fertilizer for teff production in Ethiopia.

\section{Material and Methods}

The experiment was conducted at the major teff crop producing areas of Adet, Meray and Meshenti areas.

Table 1. Descriptions of Soil type, altitude, latitude and longitude of testing locations.

\begin{tabular}{lllll}
\hline \multirow{2}{*}{ Location } & \multirow{2}{*}{$\begin{array}{l}\text { Altitude } \\
\text { (m.a.s.I) }\end{array}$} & \multirow{2}{*}{ Soil type } & \multicolumn{2}{c}{ Global positions } \\
\cline { 4 - 5 } & & Latitude & Longitude \\
\hline Adet & 2240 & Vertisol & $11^{\circ} 16^{\prime} \mathrm{N}$ & $37^{\circ} 29^{\prime} \mathrm{E}$ \\
Merawi & 1901 & Nitosol & $11^{\circ} 41^{\prime} \mathrm{N}$ & $37^{\circ} 15^{\prime} \mathrm{E}$ \\
Meshenti & 1800 & Nitosol & $11^{\circ} 47^{\prime} \mathrm{N}$ & $37^{\circ} 28^{\prime} \mathrm{E}$ \\
\hline
\end{tabular}

A total of sixteen fertilizer combinations of urea, DAP (Di Amonium phosphate) and Nano fertilizers including without fertilizer and without nano checks were tested on $2 \mathrm{~m} \mathrm{X} 1.5 \mathrm{~m}$ plot size. The materials were planted in RCBD (Randomized Complete Block Design) with three replications. Spacing between replications and plots were 1 meter and 0.5 meter respectively. The seed and fertilizer rates were used as per recommendation rate per hectare bases. The nano fertilizer was tested as early as seed dressing and field spray during tillering stage. Any farmers' suggestions and feed backs were incorporated.

Table 2. Treatment combinations.

\begin{tabular}{lll}
\hline Plot № & Seed dressing & Field spray \\
\hline 1 & $0.5 \mathrm{gm} / \mathrm{ha} \mathrm{Nano}$ & $5 \mathrm{gm} / \mathrm{ha} \mathrm{Nano}$ \\
2 & $0.5 \mathrm{gm} / \mathrm{ha} \mathrm{Nano}$ & $10 \mathrm{gm} / \mathrm{ha} \mathrm{Nano}$ \\
3 & $0.5 \mathrm{gm} / \mathrm{ha} \mathrm{Nano}$ & $39 \mathrm{gm}$ DAP and 10.8 gm Urea per plot \\
4 & $0.5 \mathrm{gm} / \mathrm{ha} \mathrm{Nano}$ & No nano/Fertilizer treatment (control) \\
5 & $1.0 \mathrm{gm} / \mathrm{ha} \mathrm{Nano}$ & $5 \mathrm{gm} / \mathrm{ha} \mathrm{Nano}$ \\
6 & $1.0 \mathrm{gm} / \mathrm{ha} \mathrm{Nano}$ & $10 \mathrm{gm} / \mathrm{ha} \mathrm{Nano}$ \\
7 & $1.0 \mathrm{gm} / \mathrm{ha} \mathrm{Nano}$ & $39 \mathrm{gm}$ DAP and 10.8 gm Urea per plot \\
8 & $1.0 \mathrm{gm} / \mathrm{ha} \mathrm{Nano}$ & No nano/Fertilizer treatment (control) \\
9 & $2.0 \mathrm{gm} / \mathrm{ha} \mathrm{Nano}$ & $5 \mathrm{gm} / \mathrm{ha} \mathrm{Nano}$ \\
10 & $2.0 \mathrm{gm} / \mathrm{ha} \mathrm{Nano}$ & $10 \mathrm{gm} / \mathrm{ha} \mathrm{Nano}$ \\
11 & $2.0 \mathrm{gm} / \mathrm{ha} \mathrm{Nano}$ & $39 \mathrm{gm}$ DAP and 10.8 gm Urea per plot \\
12 & $2.0 \mathrm{gm} / \mathrm{ha} \mathrm{Nano}$ & No nano/Fertilizer treatment (control) \\
13 & No nano trt & $5 \mathrm{gm} / \mathrm{ha} \mathrm{Nano}$ \\
14 & No nano trt & $10 \mathrm{gm} / \mathrm{ha} \mathrm{Nano}$ \\
15 & No nano trt & $39 \mathrm{gm}$ DAP and 10.8 gm Urea per plot \\
16 & No nano trt & No nano/Fertilizer treatment (control) \\
\hline
\end{tabular}

Data collection included
1) Days to maturity
2) Plant height
3) Grain yield

\section{Results and Discussion}

Adet: The performance analysis of variance at Adet (see table 3) showed that there is a significant difference between the treatments for all parameters including grain yield. The highest grain yield $(37.6 \mathrm{Q} / \mathrm{ha})$ was recorded at the treatment combination of $2 \mathrm{gm} / \mathrm{ha}$ nano seed dressing, $39 \mathrm{~g}$ DAP and
$10.8 \mathrm{~g}$ urea. And the least grain yield $(2.4 \mathrm{Q} / \mathrm{ha})$ was recorded at treatment combination of no nano and no fertilizer treatments. Here all nano treatment combinations without DAP and urea fertilizers gave grain yield less than $7 \mathrm{Q} /$ ha. Which implies that Nano fertilizers cannot act solely without DAP and Urea. This is because, if the nano fertilizers are to intensify the nitrogen use efficiency of the crop, then addition of nitrogen sources DAP and urea will be mandatory. The least maturity date (119 dates) and the highest plant height (132.2 $\mathrm{cm})$ was also recorded at a treatment combination of $2 \mathrm{gm} / \mathrm{ha}$ nano seed dressing, 39g DAP and 10.8g urea. Which implies that the crop at these treatments was vigor and matured early.

Table 3. Mean grain yield and other important agronomic characters of teff on the nano fertilizer trial at Adet.

\begin{tabular}{|c|c|c|c|c|c|}
\hline Entries & Seed treatments & Field spray & Days to maturity & Plant height (cm) & Grain yield (Q/ha) \\
\hline 1 & $0.5 \mathrm{gm} / \mathrm{ha}$ Nano & $5 \mathrm{gm} / \mathrm{ha}$ Nano & 124 & 129.5 & 4.9 \\
\hline 2 & $0.5 \mathrm{gm} / \mathrm{ha}$ Nano & $10 \mathrm{gm} / \mathrm{ha}$ Nano & 119 & 130.4 & 6.2 \\
\hline
\end{tabular}




\begin{tabular}{|c|c|c|c|c|c|}
\hline Entries & Seed treatments & Field spray & Days to maturity & Plant height (cm) & Grain yield $(\mathrm{Q} / \mathrm{ha})$ \\
\hline 3 & $0.5 \mathrm{gm} / \mathrm{ha}$ Nano & $39 \mathrm{gm}$ DAP and $10.8 \mathrm{gm}$ Urea per plot & 119 & 132.5 & 35.6 \\
\hline 4 & $0.5 \mathrm{gm} / \mathrm{ha}$ Nano & No nano/Fertilizer treatment (control) & 123 & 130.6 & 4.2 \\
\hline 5 & $1.0 \mathrm{gm} / \mathrm{ha}$ Nano & $5 \mathrm{gm} / \mathrm{ha}$ Nano & 121 & 131.6 & 5.5 \\
\hline 6 & $1.0 \mathrm{gm} / \mathrm{ha}$ Nano & $10 \mathrm{gm} / \mathrm{ha}$ Nano & 120 & 129.5 & 5.4 \\
\hline 7 & $1.0 \mathrm{gm} / \mathrm{ha}$ Nano & $39 \mathrm{gm}$ DAP and $10.8 \mathrm{gm}$ Urea per plot & 121 & 131.5 & 36.5 \\
\hline 8 & $1.0 \mathrm{gm} / \mathrm{ha}$ Nano & No nano/Fertilizer treatment (control) & 121 & 129.8 & 5.4 \\
\hline 9 & $2.0 \mathrm{gm} / \mathrm{ha}$ Nano & $5 \mathrm{gm} / \mathrm{ha}$ Nano & 123 & 130.7 & 5.5 \\
\hline 11 & $2.0 \mathrm{gm} / \mathrm{ha}$ Nano & 39 gm DAP and 10.8 gm Urea per plot & 119 & 132.2 & 37.6 \\
\hline 12 & $2.0 \mathrm{gm} / \mathrm{ha}$ Nano & No nano/Fertilizer treatment (control) & 122 & 129.4 & 5.02 \\
\hline 13 & No nano trt & $5 \mathrm{gm} / \mathrm{ha}$ Nano & 123 & 131.2 & 5.12 \\
\hline 14 & No nano trt & $10 \mathrm{gm} / \mathrm{ha}$ Nano & 120 & 130.2 & 5.45 \\
\hline 15 & No nano trt & 39 gm DAP and 10.8 gm Urea per plot & 121 & 131.8 & 36 \\
\hline 16 & No nano trt & No nano/Fertilizer treatment (control) & 123 & 129 & 2.4 \\
\hline Mean & & & 121.56 & 130.59 & 12.91 \\
\hline
\end{tabular}

Meshenti: Analysis of variance at Meshenti (see table 4) showed that there is a significant difference between the treatments for all parameters including grain yield. The highest grain yield $(37.9 \mathrm{Q} / \mathrm{ha})$ was recorded at the treatment combination of $2 \mathrm{gm} / \mathrm{ha}$ nano seed dressing, $39 \mathrm{~g}$ DAP and $10.8 \mathrm{~g}$ urea. And the least grain yield (2.6 Q/ha) was recorded at treatment combination of no nano and no fertilizer treatments. Here all nano treatment combinations without
DAP and urea fertilizers gave grain yield less than 7Q/ha. Which again implies that Nano fertilizers cannot act solely without DAP and Urea at Meshenti too. The least maturity date $(120$ dates $)$ and the highest plant height $(133.1 \mathrm{~cm})$ was also recorded at a treatment combination of $2 \mathrm{gm} / \mathrm{ha}$ nano seed dressing, 39g DAP and $10.8 \mathrm{~g}$ urea. This implies that the crop at these treatments was vigor and matures early like the other locations.

Table 4. Mean grain yield and other important agronomic characters of teff on the nano fertilizer trial at Meshenti.

\begin{tabular}{|c|c|c|c|c|c|}
\hline Entries & Seed treatments & Field spray & Days to maturity & Plant height (cm) & Grain yield $(\mathrm{Q} / \mathrm{ha})$ \\
\hline 1 & $0.5 \mathrm{gm} / \mathrm{ha}$ Nano & $5 \mathrm{gm} / \mathrm{ha}$ Nano & 124 & 128.4 & 5.2 \\
\hline 2 & $0.5 \mathrm{gm} / \mathrm{ha}$ Nano & $10 \mathrm{gm} / \mathrm{ha}$ Nano & 121 & 131.2 & 5.9 \\
\hline 3 & $0.5 \mathrm{gm} / \mathrm{ha}$ Nano & 39 gm DAP and 10.8 gm Urea per plot & 120 & 132.3 & 35.8 \\
\hline 4 & $0.5 \mathrm{gm} / \mathrm{ha}$ Nano & No nano/Fertilizer treatment (control) & 121 & 131.3 & 3.9 \\
\hline 5 & $1.0 \mathrm{gm} / \mathrm{ha}$ Nano & $5 \mathrm{gm} / \mathrm{ha}$ Nano & 123 & 132.2 & 5.1 \\
\hline 6 & $1.0 \mathrm{gm} / \mathrm{ha}$ Nano & $10 \mathrm{gm} / \mathrm{ha}$ Nano & 123 & 130.2 & 5.6 \\
\hline 7 & $1.0 \mathrm{gm} / \mathrm{ha}$ Nano & 39 gm DAP and 10.8 gm Urea per plot & 120 & 132.1 & 37.0 \\
\hline 9 & $2.0 \mathrm{gm} / \mathrm{ha}$ Nano & $5 \mathrm{gm} / \mathrm{ha}$ Nano & 123 & 131.3 & 5.3 \\
\hline 10 & $2.0 \mathrm{gm} / \mathrm{ha}$ Nano & $10 \mathrm{gm} / \mathrm{ha}$ Nano & 123 & 130.0 & 5.6 \\
\hline 11 & $2.0 \mathrm{gm} / \mathrm{ha}$ Nano & 39 gm DAP and 10.8 gm Urea per plot & 124 & 133.1 & 37.9 \\
\hline 12 & $2.0 \mathrm{gm} / \mathrm{ha}$ Nano & No nano/Fertilizer treatment (control) & 120 & 130.4 & 5.14 \\
\hline 13 & No nano trt & $5 \mathrm{gm} / \mathrm{ha}$ Nano & 121 & 129.8 & 5.20 \\
\hline 14 & No nano trt & $10 \mathrm{gm} / \mathrm{ha}$ Nano & 123 & 131.0 & 5.23 \\
\hline 15 & No nano trt & 39 gm DAP and 10.8 gm Urea per plot & 122 & 131.0 & 36.2 \\
\hline $\mathrm{CV} \%$ & & & 2.14 & 5.7 & 8.4 \\
\hline $\operatorname{LSD}(0.05)$ & & & $1.96 * *$ & $2.04 * *$ & $0.91 * *$ \\
\hline
\end{tabular}

Meray: Analysis of variance at Meray (see table 5) showed that there is a significant difference between the treatments for all parameters including grain yield. The highest grain yield $(38.5 \mathrm{Q} / \mathrm{ha})$ was recorded at the treatment combination of $2 \mathrm{gm} /$ ha nano seed dressing, $39 \mathrm{~g}$ DAP and $10.8 \mathrm{~g}$ urea. And the least grain yield $(2.5 \mathrm{Q} / \mathrm{ha})$ was recorded at treatment combination of no nano and no fertilizer treatments. Here all nano treatment combinations without DAP and urea fertilizers gave grain yield less yields than together with together with them. Which again implies that Nano fertilizers cannot act solely without DAP and Urea at Meray too. The least maturity date (118 dates) and the highest plant height $(135.5 \mathrm{~cm})$ was also recorded at a treatment combination of $2 \mathrm{gm} /$ ha nano seed dressing, $39 \mathrm{~g}$ DAP and $10.8 \mathrm{~g}$ urea. This implies that the crop at these treatments was vigor and matures early like Adet and Meshenti too.

Table 5. Mean grain yield and other important agronomic characters of teff on the nano fertilizer trial at Meray.

\begin{tabular}{|c|c|c|c|c|c|}
\hline Entries & Seed treatments & Field spray & Days to maturity & Plant height (cm) & Grain yield (Q/ha) \\
\hline 1 & $0.5 \mathrm{gm} / \mathrm{ha}$ Nano & 5gm/ha Nano & 126 & 133.3 & 5.2 \\
\hline 2 & $0.5 \mathrm{gm} / \mathrm{ha}$ Nano & $10 \mathrm{gm} / \mathrm{ha}$ Nano & 121 & 124.5 & 6.2 \\
\hline
\end{tabular}




\begin{tabular}{|c|c|c|c|c|c|}
\hline Entries & Seed treatments & Field spray & Days to maturity & Plant height (cm) & Grain yield $(\mathrm{Q} / \mathrm{ha})$ \\
\hline 3 & $0.5 \mathrm{gm} / \mathrm{ha} \mathrm{Nano}$ & $39 \mathrm{gm} \mathrm{DAP}$ and $10.8 \mathrm{gm}$ Urea per plot & 120 & 133.1 & 39 \\
\hline 4 & $0.5 \mathrm{gm} / \mathrm{ha}$ Nano & No nano/Fertilizer treatment (control) & 119 & 132.6 & 5.4 \\
\hline 5 & $1.0 \mathrm{gm} / \mathrm{ha} \mathrm{Nano}$ & $5 \mathrm{gm} / \mathrm{ha} \mathrm{Nano}$ & 122 & 123.2 & 5.6 \\
\hline 6 & 1.0gm/ha Nano & $10 \mathrm{gm} /$ ha Nano & 126 & 126.1 & 5.8 \\
\hline 7 & $1.0 \mathrm{gm} / \mathrm{ha}$ Nano & 39 gm DAP and 10.8 gm Urea per plot & 120 & 133.6 & 37.5 \\
\hline 8 & $1.0 \mathrm{gm} / \mathrm{ha}$ Nano & No nano/Fertilizer treatment (control) & 120 & 130.4 & 4.7 \\
\hline 9 & $2.0 \mathrm{gm} / \mathrm{ha} \mathrm{Nano}$ & $5 \mathrm{gm} / \mathrm{ha}$ Nano & 128 & 131.6 & 6 \\
\hline 10 & $2.0 \mathrm{gm} / \mathrm{ha}$ Nano & $10 \mathrm{gm} / \mathrm{ha}$ Nano & 127 & 125.1 & 5.1 \\
\hline 11 & $2.0 \mathrm{gm} / \mathrm{ha}$ Nano & $39 \mathrm{gm} \mathrm{DAP}$ and $10.8 \mathrm{gm}$ Urea per plot & 118 & 135.5 & 38.5 \\
\hline 12 & $2.0 \mathrm{gm} / \mathrm{ha}$ Nano & No nano/Fertilizer treatment (control) & 117 & 125.7 & 5.56 \\
\hline 13 & No nano trt & $5 \mathrm{gm} / \mathrm{ha} \mathrm{Nano}$ & 119 & 130.2 & 6.48 \\
\hline 14 & No nano trt & $10 \mathrm{gm} / \mathrm{ha}$ Nano & 126 & 124.3 & 4.92 \\
\hline 15 & No nano trt & $39 \mathrm{gm} \mathrm{DAP}$ and $10.8 \mathrm{gm}$ Urea per plot & 129 & 131 & 37.3 \\
\hline 16 & No nano trt & No nano/Fertilizer treatment (control) & 116 & 125.4 & 2.5 \\
\hline \multirow{2}{*}{\multicolumn{6}{|c|}{$\begin{array}{l}\text { Mean } \\
\mathrm{CV} \%\end{array}$}} \\
\hline & & & & & \\
\hline $\operatorname{LSD}(0.05)$ & & & & & \\
\hline
\end{tabular}

Combined: The performances of nano fertilizer over all locations have shown consistence results at all locations. Analysis of variance (see table 6) showed that there is a significant difference between the treatments for all parameters including grain yield. The highest grain yield (38 $\mathrm{Q} / \mathrm{ha}$ ) was recorded at the treatment combination of $2 \mathrm{gm} / \mathrm{ha}$ nano seed dressing, 39g DAP and $10.8 \mathrm{~g}$ urea. And the least grain yield $(2.5 \mathrm{Q} / \mathrm{ha})$ was recorded at treatment combination of no nano and no fertilizer treatments. Here all nano treatment combinations without DAP and urea fertilizers gave grain yield less than $7 \mathrm{Q} /$ ha. Which implies that Nano fertilizers cannot act solely without DAP and Urea. This is because, if the nano fertilizers are to intensify the nitrogen use efficiency of the crop, then addition of nitrogen sources DAP and urea will be mandatory. The least maturity date (119 dates) and the highest plant height $(132.4 \mathrm{~cm})$ was also recorded at a treatment combination of $2 \mathrm{gm} / \mathrm{ha}$ nano seed dressing, 39g DAP and $10.8 \mathrm{~g}$ urea. Which implies that the crop at these treatments were vigor so that it matures early.

Table 6. Mean grain yield and other important agronomic characters of teff on the nano fertilizer trial combined over locations.

\begin{tabular}{|c|c|c|c|c|c|}
\hline Entries & Seed treatments & Field spray & Days to maturity & Plant height (cm) & Grain yield $(\mathrm{Q} / \mathrm{ha})$ \\
\hline 1 & $0.5 \mathrm{gm} / \mathrm{ha}$ Nano & $5 \mathrm{gm} / \mathrm{ha}$ Nano & 125 & 130.4 & 5.1 \\
\hline 2 & $0.5 \mathrm{gm} / \mathrm{ha}$ Nano & $10 \mathrm{gm} / \mathrm{ha}$ Nano & 120 & 128.7 & 6.1 \\
\hline 3 & $0.5 \mathrm{gm} / \mathrm{ha}$ Nano & 39 gm DAP and 10.8 gm Urea per plot & 119 & 133.7 & 36.8 \\
\hline 4 & $0.5 \mathrm{gm} / \mathrm{ha}$ Nano & No nano/Fertilizer treatment (control) & 121 & 131.5 & 4.5 \\
\hline 5 & $1.0 \mathrm{gm} / \mathrm{ha}$ Nano & $5 \mathrm{gm} / \mathrm{ha}$ Nano & 122 & 129.0 & 5.4 \\
\hline 6 & $1.0 \mathrm{gm} / \mathrm{ha}$ Nano & $10 \mathrm{gm} / \mathrm{ha}$ Nano & 123 & 128.6 & 5.6 \\
\hline 8 & $1.0 \mathrm{gm} / \mathrm{ha}$ Nano & No nano/Fertilizer treatment (control) & 120 & 130.2 & 5.2 \\
\hline 9 & $2.0 \mathrm{gm} / \mathrm{ha}$ Nano & $5 \mathrm{gm} / \mathrm{ha}$ Nano & 124 & 131.2 & 5.6 \\
\hline 10 & $2.0 \mathrm{gm} / \mathrm{ha}$ Nano & $10 \mathrm{gm} / \mathrm{ha}$ Nano & 125 & 128.2 & 5.5 \\
\hline 11 & $2.0 \mathrm{gm} / \mathrm{ha}$ Nano & 39 gm DAP and 10.8 gm Urea per plot & 119 & 132.4 & 38.0 \\
\hline 12 & $2.0 \mathrm{gm} / \mathrm{ha}$ Nano & No nano/Fertilizer treatment (control) & 121 & 128.5 & 5.24 \\
\hline 13 & No nano trt & $5 \mathrm{gm} / \mathrm{ha}$ Nano & 121 & 130.4 & 5.6 \\
\hline 14 & No nano trt & $10 \mathrm{gm} / \mathrm{ha}$ Nano & 123 & 128.5 & 5.2 \\
\hline 16 & No nano trt & No nano/Fertilizer treatment (control) & 120 & 128.2 & 2.5 \\
\hline Mean & & & 121.68 & 130.20 & 12.90 \\
\hline $\mathrm{CV} \%$ & & & 1.95 & 6.71 & 9.32 \\
\hline $\operatorname{LSD}(0.05)$ & & & $2.50 * *$ & $1.44 * *$ & $0.85 * *$ \\
\hline
\end{tabular}

\section{Market Analysis}

The marginal rate of return which is gained from Nano over DAP and urea has to be greater than the initial cost of Nano fertilizer. Or in other words, the cost of the additional yield which is gained from application of Nano in addition to DAP and urea must be greater than the initial cost of the added nano. There is a $1.5 \mathrm{Q} /$ ha difference between the nano without DAP and urea (36.5Q/ha) and nano with DAP and urea $(38 \mathrm{Q} / \mathrm{ha})$. The current price of teff is 1,500 Ethiopian
Birr. For a hectare of land four packet of nano fertilizer is need. If we take the price of nano packet \$11 US dollars, then \$44 US dollars or 880 Ethiopian birr will be needed for a hectare of land. So, there is a difference of 700 Ethiopian birr or \$35 US dollars. Hence the nano fertilizer is cost effective.

\section{Conclusion and Recommendation}

The nano fertilizer are latest relevant technologies. Even 
though it seems difficult to get the market opportunity, I strongly recommend the nano fertilizers especially for large state and investment farms. Besides, as the technology is new and needs technical procedure, continues trainings for the farmers are important. Otherwise, miss use of it might cause toxicity of those small scale farms.

\section{References}

[1] Abobatta WF., "Nanotechnology Application in Agriculture". Acta Scientific Agriculture 2: 99-102 (2018).

[2] Aysan G., Kamran A., Mohammadreza Y. and Hamidreza A., "Effects of Nano-Potassium and Nano-Calcium Chelated Fertilizers on Qualitative and Quantitative Characteristics of Ocimum basilicum". IJPRS 3: 235-241 (2014).

[3] Conley D. J, Paerl HW., Howarth RW., Boesch DF. and Seitzinger SP., Ecology controlling eutrophication: nitrogen and phosphorus. Science 323: 1014-1015 (2009).

[4] Corradini E., de Moura M. R. and Mattoso L. K.,"A Preliminary Study of the Incorporation of NPK Fertilizer into Chitosan Nanoparticles", DOI: 10.3144/expresspolymlett.2010.6, express polymer letters vol. 4, no. 8 (2010) 509-515, 30 April 2010.

[5] Correll DL., "The role of phosphorus in the eutrophication of receiving waters: a review”. J. Environ 27: 261-266 (1998).

[6] De Rosa MC., Monreal C., Schnitzer M., Walsh R. and Sultan Y., "Nanotechnology in fertilizers". Nat Nano-technol 5: 91 (2010).

[7] EPA "Healthy lawn, healthy environment, prevention and pesticide and toxic substances". 735-K-04-001 (2004).
[8] Guo JH., Liu XJ., Zhang Y., Shen JL., Han WX. et al. Significant acidification in major Chinese croplands. Science 327: 1008-1010 (2010).

[9] Gutierrez FJ., Mussons ML., Gaton P. and Rojo R., Nanotechnology and Food Industry. Scientific, Health and Social Aspects of the Food Industry, In Tech, Croatia Book Chapter (2011).

[10] Mousavi SR. and Rezaei M.," Nanotechnology in agriculture and food production”. J. Appl. Environ. Biol Sci 1: 414-419 (2011).

[11] Sadik O. A., Zhou A. L., Kikandi S., Wang N. Q. and Varner K., " Sensors As Tools For Quantitation, Nanotoxicity And Nano Monitoring Assessment Of Engineered Nanomaterials", Journal of Environmental Monitoring, DOI: 10.1039/b912860c, 14 September 2009.

[12] Tarafdar JC., Raliya R., Mahawar H. and Rathore I.," Development of Zinc Nano-fertilizer to Enhance Crop Production in Pearl Millet (Pennisetum americanum)". Agricultural Research 3: 257-262 (2014).

[13] Tarafdar J. and Raliya C., "Rapid, low-cost, and ecofriendly approach for iron nanoparticle synthesis using aspergillus oryzae", TFR9. Journal of Nanoparticles Article ID: 141274, pp: 4 pages (2013).

[14] Tisdale SL., Nelson WL. and Beaton JD.," Soil Fertility and Fertilizer". 4th Edition, Macmillan Publishing Company, New York. pp: 754 (1985).

[15] Tothill I. E., "Biosensors developments and potential applications in the agricultural diagnosis sector", Elsiver Science, Computers and electronics in agriculture, 01681699/01, 205-218, 30 (2001). 